\title{
New 9-Hydroxybriarane Diterpenoids from a Gorgonian Coral Briareum sp. (Briareidae)
}

\author{
Yin-Di Su ${ }^{1,2,+}$, Chun-Sung Sung ${ }^{3,4,+}$, Zhi-Hong Wen ${ }^{1,5}$, Yu-Hsin Chen ${ }^{2,6}$, Yu-Chia Chang ${ }^{2,5}$, \\ Jih-Jung Chen ${ }^{7}$, Lee-Shing Fang ${ }^{8}$, Yang-Chang $W u^{9,10,11,12, *}$, Jyh-Horng Sheu ${ }^{1,5, *}$ and \\ Ping-Jyun Sung 1,2,10,12,13,*
}

Received: 30 November 2015; Accepted: 5 January 2016; Published: 9 January 2016

Academic Editor: Vassilios Roussis

1 Department of Marine Biotechnology \& Resources and Asia-Pacific Ocean Research Center, National Sun Yat-sen University, Kaohsiung 804, Taiwan; gobetter04@yahoo.com.tw (Y.-D.S.); wzh@mail.nsysu.edu.tw (Z.-H.W.)

2 National Museum of Marine Biology \& Aquarium, Pingtung 944, Taiwan; kb5634@yahoo.com.tw (Y.-H.C.); jay0404@gmail.com (Y.-C.C.)

3 Department of Anesthesiology, Taipei Veterans General Hospital, Taipei 112, Taiwan; sung6119@gmail.com

4 School of Medicine, National Yang-Ming University, Taipei 112, Taiwan

5 Doctoral Degree Program of Marine Biotechnology, National Sun Yat-sen University \& Academia Sinica, Kaohsiung 804, Taiwan

6 Department of Life Science and Institute of Biotechnology, National Dong Hwa University, Hualien 974, Taiwan

7 Department of Pharmacy \& Graduate Institute of Pharmaceutical Technology, Tajen University, Pingtung 907, Taiwan; jjchen@tajen.edu.tw

8 Department of Sport, Health and Leisure, Cheng Shiu University, Kaohsiung 833, Taiwan; lsfang@csu.edu.tw

9 School of Pharmacy, College of Pharmacy, China Medical University, Taichung 404, Taiwan

10 Chinese Medicine Research and Development Center, China Medical University Hospital, Taichung 404, Taiwan

11 Center for Molecular Medicine, China Medical University Hospital, Taichung 404, Taiwan

12 Graduate Institute of Natural Products, Kaohsiung Medical University, Kaohsiung 807, Taiwan

13 Graduate Institute of Marine Biology, National Dong Hwa University, Pingtung 944, Taiwan

* Correspondence: yachwu@mail.cmu.edu.tw (Y.-C.W.); sheu@mail.nsysu.edu.tw (J.-H.S.); pjsung@nmmba.gov.tw (P.-J.S.); Tel.: +886-4-2205-7513 (Y.-C.W.); +886-7-5252-000 (ext. 5030) (J.-H.S.); +886-8-882-5037 (P.-J.S.); Fax: +886-4-2206-0248 (Y.-C.W.); +886-7-5255-020 (J.-H.S.); +886-8-882-5087 (P.-J.S.)

+ These authors contributed equally to this work.

Abstract: Six new 9-hydroxybriarane diterpenoids, briarenolides ZI-ZVI (1-6), were isolated from a gorgonian coral Briareum sp. The structures of briaranes 1-6 were elucidated by spectroscopic methods and by comparison of their spectroscopic data with those of related analogues. Briarenolides ZII (2) and ZVI (6) were found to significantly inhibit the expression of the pro-inflammatory inducible nitric oxide synthase (iNOS) protein of lipopolysaccharide (LPS)-stimulated RAW264.7 macrophage cells.

Keywords: Briareum; briarenolide; briarane; gorgonian; anti-inflammatory; iNOS

\section{Introduction}

The briarane-type diterpenoid (3,8-cyclized cembranoid), $2 \beta$-acetoxy-2-(debutyryloxy)-stecholide E, was first isolated from the gorgonian coral Briareum sp. in 1996 [1]. Since then, hundreds of compounds of this type have been obtained from various Taiwanese gorgonian corals, such as Briareum, Junceella and Ellisella spp. [2-6], that have been located off the coast of Taiwan. Recently, in a sample collected at the southern tip of Taiwan, as Briareum sp. (family Briareidae), we identified six new 
briaranes, briarenolides ZI-ZVI (1-6) (Figure 1). In this report, we isolate and determine the structures of these briaranes, in addition to studying their anti-inflammatory properties.

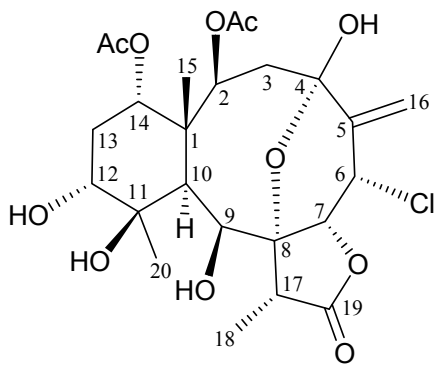

1

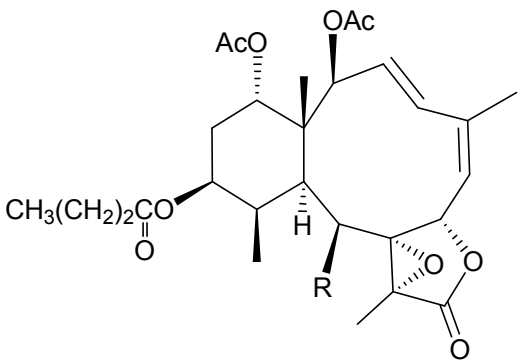

2: $\mathrm{R}=\mathrm{OH}, 7: \mathrm{R}=\mathrm{OAC}$

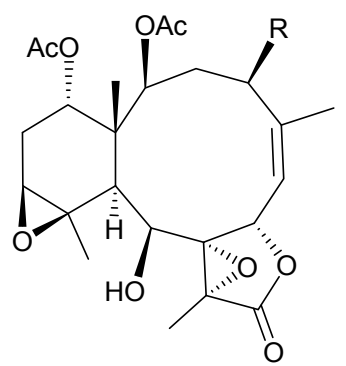

3: $\mathrm{R}=\mathrm{OH}, 8: \mathrm{R}=\mathrm{H}$

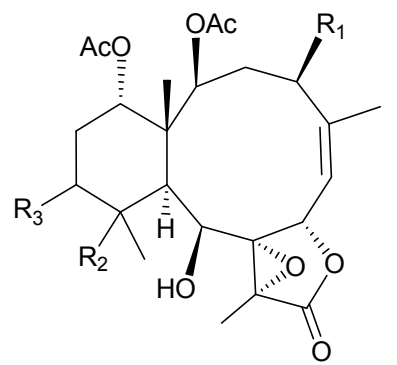

4: $\mathrm{R}_{1}=\mathrm{OH}, \mathrm{R}_{2}=\alpha-\mathrm{H}, \mathrm{R}_{3}=\alpha-\mathrm{OC}(\mathrm{O})\left(\mathrm{CH}_{2}\right)_{2} \mathrm{CH}_{3}$

5: $\mathrm{R}_{1}=\mathrm{H}, \mathrm{R}_{2}=\beta-\mathrm{OH}, \mathrm{R}_{3}=\alpha-\mathrm{OH}$

6: $\mathrm{R}_{1}=\mathrm{OAc}, \mathrm{R}_{2}=\alpha-\mathrm{H}, \mathrm{R}_{3}=\beta-\mathrm{OH}$

9: $\mathrm{R}_{1}=\mathrm{H}, \mathrm{R}_{2}=\beta-\mathrm{OH}, \mathrm{R}_{3}=\alpha-\mathrm{OC}(\mathrm{O})\left(\mathrm{CH}_{2}\right)_{2} \mathrm{CH}_{3}$

10: $\mathrm{R}_{1}=\mathrm{H}, \mathrm{R}_{2}=\alpha-\mathrm{H}, \mathrm{R}_{3}=\beta-\mathrm{OH}$

Figure 1. The structures of briarenolides ZI-ZVI (1-6), excavatolide F (7), $2 \beta$-acetoxy-2(debutyryloxy)-stecholideE (8), excavatolide Z (9) and excavatolide E (10).

\section{Results and Discussion}

The molecular formula of a new briarane, briarenolide $\mathrm{ZI}(\mathbf{1})$, was determined as $\mathrm{C}_{24} \mathrm{H}_{33} \mathrm{ClO}_{11}$ (eight degrees of unsaturation) by high-resolution electrospray ionization mass spectrum (HRESIMS) at $m / z 555.16025$ (calcd. for $\mathrm{C}_{24} \mathrm{H}_{33} \mathrm{ClO}_{11}+\mathrm{Na}, 555.16036$ ). The IR of 1 showed absorptions at 1715, 1769 and $3382 \mathrm{~cm}^{-1}$, which were consistent with the presence of ester, $\gamma$-lactone and hydroxy groups. The ${ }^{13} \mathrm{C}$ NMR spectrum (Table 1 ) suggested that 1 possessed an exocyclic carbon-carbon double bond based on signals at $\delta_{C} 138.6(\mathrm{C}-5)$ and $116.9\left(\mathrm{CH}_{2}-16\right)$, which was confirmed by the ${ }^{1} \mathrm{H}$ NMR spectrum of 1 (Table 1), which showed two olefin proton signals at $\delta_{\mathrm{H}} 5.88(1 \mathrm{H}, \mathrm{dd}, J=2.4,1.2 \mathrm{~Hz}, \mathrm{H}-16 \mathrm{a})$ and $5.64(1 \mathrm{H}, \mathrm{dd}, J=2.4,1.2 \mathrm{~Hz}, \mathrm{H}-16 \mathrm{~b})$. Three carbonyl resonances at $\delta_{\mathrm{C}} 175.3(\mathrm{C}-19), 173.4$ and 169.3 ( $2 \times$ ester carbonyls) revealed the presence of one $\gamma$-lactone and two ester groups in 1 ; two acetyl methyls $\left(\delta_{\mathrm{H}} 2.06, \mathrm{~s}, 2 \times 3 \mathrm{H}\right)$ were also observed. According to the overall unsaturation data, it was concluded that 1 was a diterpenoid molecule possessing four rings.

${ }^{1} \mathrm{H}$ NMR coupling information in the ${ }^{1} \mathrm{H}-{ }^{1} \mathrm{H}$ correlation spectroscopy (COSY) spectrum of $\mathbf{1}$ enabled identification of the $\mathrm{H}-2 / \mathrm{H}_{2}-3, \mathrm{H}-6 / \mathrm{H}-7, \mathrm{H}-12 / \mathrm{H}_{2}-13 / \mathrm{H}-14, \mathrm{H}-6 / \mathrm{H}_{2}-16$ (by allylic coupling) and $\mathrm{H}-17 / \mathrm{H}_{3}-18$ units (Table 1 ). The heteronuclear multiple bond coherence (HMBC) correlations between protons and quaternary carbons of $\mathbf{1}\left(\mathrm{H}-2, \mathrm{H}_{2}-3, \mathrm{H}-10, \mathrm{H}_{2}-13, \mathrm{H}_{3}-15 / \mathrm{C}-1 ; \mathrm{H}-2, \mathrm{H}_{2}-3, \mathrm{H}_{2}-16\right.$, $\mathrm{OH}-4 / \mathrm{C}-4 ; \mathrm{H}-16 \mathrm{~b}, \mathrm{OH}-4 / \mathrm{C}-5$; H-10, $\mathrm{H}_{3}-18$, OH-9/C-8; $\mathrm{H}_{3}-20 / \mathrm{C}-11$ and H-17, $\left.\mathrm{H}_{3}-18 / \mathrm{C}-19\right)$ permitted elucidation of the carbon skeleton (Table 1). HMBC correlations between $\mathrm{H}_{2}-16 / \mathrm{C}-4,-5$ and -6 indicated an exocyclic double bond at $\mathrm{C}-5$, which was further confirmed by the allylic coupling between $\mathrm{H}_{2}-16 / \mathrm{H}-6$. HMBC correlations between $\mathrm{H}_{3}-15 / \mathrm{C}-1,-2,-10$ and -14 and $\mathrm{H}-2$ and $\mathrm{H}-10 / \mathrm{C}-15$, revealed that the ring junction $\mathrm{C}-15$ methyl group was located at $\mathrm{C}-1$. Furthermore, an HMBC correlation between H-2 $\left(\delta_{\mathrm{H}} 5.09\right)$ and the acetate carbonyl $\left(\delta_{\mathrm{C}} 173.4\right)$ revealed the presence of an acetate ester at C-2; and an HMBC correlation between a hydroxy proton $\left(\delta_{\mathrm{H}} 6.50\right)$ and $\mathrm{C}-4$ oxygenated quaternary carbon suggested the presence of a hydroxy group at $\mathrm{C}-4$. The $\mathrm{C}-4$ hydroxy group was determined to be part of a hemiketal constellation on the basis of a characteristic carbon signal at $\delta_{\mathrm{C}}$ 96.7. ${ }^{1} \mathrm{H}-{ }^{1} \mathrm{H}$ COSY correlations between $\mathrm{OH}-9 / \mathrm{H}-9$ and $\mathrm{OH}-12 / \mathrm{H}-12$ suggested the presence of the 
hydroxy groups at C-9 and C-12. A carbon signal at $\delta_{\mathrm{C}} 81.8(\mathrm{C}-8)$ indicated ${ }^{3} J$-coupling with protons at $\delta_{\mathrm{H}} 2.23(\mathrm{H}-10), 1.33\left(\mathrm{H}_{3}-18\right)$ and $2.73(\mathrm{OH}-9)$. Therefore, the remaining hydroxy and acetoxy groups had to be positioned at C-11 and C-14, respectively, as indicated by analysis of ${ }^{1} \mathrm{H}-{ }^{1} \mathrm{H}$ COSY correlations and characteristic NMR signal analysis. The intensity of the sodiated molecules $[\mathrm{M}+2+\mathrm{Na}]^{+}$isotope peak observed in the ESIMS and HRESIMS spectra $\left([\mathrm{M}+\mathrm{Na}]^{+}:[\mathrm{M}+2+\mathrm{Na}]^{+}=3: 1\right)$ was evidence of the presence of one chlorine atom in 1 . The methine unit at $\delta_{\mathrm{C}} 56.2$ was more shielded than expected for an oxygenated carbon and was correlated to the methine proton at $\delta_{\mathrm{H}} 5.54(\mathrm{H}-6)$ in the heteronuclear multiple quantum coherence (HMQC) spectrum, and this proton signal was ${ }^{3} \mathrm{~J}$-correlated with $\mathrm{H}-7$ $\left(\delta_{\mathrm{H}} 4.73\right)$ in the ${ }^{1} \mathrm{H}-{ }^{1} \mathrm{H}$ COSY spectrum, which proved that a chlorine atom was attached at C-6. These data, together with the HMBC correlations between $\mathrm{H}-17 / \mathrm{C}-9,-18$ and -19 and $\mathrm{H}_{3}-18 / \mathrm{C}-8,-17$ and -19 , established the molecular framework of $\mathbf{1}$.

Table 1. ${ }^{1} \mathrm{H}\left(400 \mathrm{MHz}, \mathrm{CDCl}_{3}\right)$ and ${ }^{13} \mathrm{C}\left(100 \mathrm{MHz}, \mathrm{CDCl}_{3}\right) \mathrm{NMR}$ data and ${ }^{1} \mathrm{H}-{ }^{1} \mathrm{H}$ COSY (correlation spectroscopy) and HMBC (heteronuclear multiple bond coherence) correlations for briarane 1.

\begin{tabular}{|c|c|c|c|c|}
\hline Position & $\delta_{H}(J$ in $\mathrm{Hz})$ & $\delta_{\mathrm{C}}$, Multiple & ${ }^{1} \mathrm{H}-{ }^{1} \mathrm{H}$ COSY & НМВС \\
\hline 1 & - & $45.6, \mathrm{C}$ & - & - \\
\hline 2 & $5.09 \mathrm{~d}(6.4)$ & $73.4, \mathrm{CH}$ & $\mathrm{H}_{2}-3$ & $\begin{array}{c}\text { C-1, }-4,-15, \text { acetate } \\
\text { carbonyl }\end{array}$ \\
\hline 3 & $3.73 \mathrm{dd}(16.0,6.4) ; 1.46 \mathrm{~d}(16.0)$ & 41.7, $\mathrm{CH}_{2}$ & $\mathrm{H}-2$ & C $-1,-2,-4$ \\
\hline 4 & - & $96.7, \mathrm{C}$ & - & - \\
\hline 5 & - & $138.6, \mathrm{C}$ & - & - \\
\hline 6 & $5.54 \mathrm{dt}(2.8,2.4)$ & $56.2, \mathrm{CH}$ & $\mathrm{H}-7, \mathrm{H}_{2}-16$ & n. o. ${ }^{a}$ \\
\hline 7 & $4.73 \mathrm{~d}(2.8)$ & $79.8, \mathrm{CH}$ & H-6 & n. o. \\
\hline 8 & - & $81.8, \mathrm{C}$ & - & - \\
\hline 9 & $4.88 \mathrm{~d}(3.2)$ & $76.9, \mathrm{CH}$ & $\mathrm{H}-10, \mathrm{OH}-9$ & n. o. \\
\hline 10 & $2.23 \mathrm{~s}$ & $40.5, \mathrm{CH}$ & H-9 & $C-1,-2,-8,-9,-15$ \\
\hline 11 & - & $78.5, \mathrm{C}$ & - & - \\
\hline 12 & $3.50 \mathrm{br} \mathrm{s}$ & $76.1, \mathrm{CH}$ & $\mathrm{H}_{2}-13, \mathrm{OH}-12$ & n. o. \\
\hline 13 & 2.44 ddd $(15.6,4.0,2.8) ; 1.98$ ddd $(15.6,3.2,2.8)$ & 28.0, $\mathrm{CH}_{2}$ & $\mathrm{H}-12, \mathrm{H}-14$ & $\mathrm{C}-1$ \\
\hline 14 & $5.22 \mathrm{t}(2.8)$ & $76.3, \mathrm{CH}$ & $\mathrm{H}_{2}-13$ & n. o. \\
\hline 15 & $1.55 \mathrm{~s}$ & $16.5, \mathrm{CH}_{3}$ & - & $C-1,-2,-10,-14$ \\
\hline $16 a / b$ & $5.88 \mathrm{dd}(2.4,1.2) ; 5.64 \mathrm{dd}(2.4,1.2)$ & $116.9, \mathrm{CH}_{2}$ & H-6 & C $-4,-5,-6$ \\
\hline 17 & $2.58 \mathrm{q}(7.2)$ & $50.4, \mathrm{CH}$ & $\mathrm{H}_{3}-18$ & $C-9,-18,-19$ \\
\hline 18 & $1.33 \mathrm{~d}(7.2)$ & $8.2, \mathrm{CH}_{3}$ & $\mathrm{H}-17$ & $C-8,-17,-19$ \\
\hline 19 & - & $175.3, \mathrm{C}$ & - & - \\
\hline 20 & $1.56 \mathrm{~s}$ & $28.9, \mathrm{CH}_{3}$ & - & $C-10,-11,-12$ \\
\hline \multirow[t]{2}{*}{ OAc-2 } & - & $173.4, \mathrm{C}$ & - & - \\
\hline & $2.06 \mathrm{~s}$ & 21.3, $\mathrm{CH}_{3}$ & - & Acetate carbonyl \\
\hline \multirow[t]{2}{*}{ OAc-14 } & - & $169.3, \mathrm{C}$ & - & - \\
\hline & $2.06 \mathrm{~s}$ & $21.1, \mathrm{CH}_{3}$ & - & Acetate carbonyl \\
\hline $\mathrm{OH}-4$ & $6.50 \mathrm{~s}$ & - & - & $C-3,-4,-5$ \\
\hline $\mathrm{OH}-9$ & $2.73 \mathrm{~d}(3.2)$ & - & H-9 & C-8 \\
\hline $\mathrm{OH}-12$ & $2.67 \mathrm{br} \mathrm{s}$ & - & $\mathrm{H}-12$ & n. o. \\
\hline
\end{tabular}

The relative configuration of $\mathbf{1}$ was elucidated on the basis of a nuclear Overhauser effect spectroscopy (NOESY) experiment and by vicinal ${ }^{1} \mathrm{H}-{ }^{1} \mathrm{H}$ proton coupling constant analysis. Most naturally-occurring briarane natural products have Me-15 in the $\beta$-orientation and $\mathrm{H}-10$ in the $\alpha$-orientation [2-6], which were verified by the absence of a correlation between these two groups. In the NOESY experiment of $\mathbf{1}$ (Figure 2), $\mathrm{H}-10$ correlated with $\mathrm{H}-2, \mathrm{H}-9$ and $\mathrm{H}_{3}-20$, indicating that these protons were situated on the same face; they were assigned as $\alpha$ protons, as $C-15$ methyl was $\beta$-oriented at $\mathrm{C}-1$. The oxymethine proton $\mathrm{H}-14$ was found to exhibit a response with $\mathrm{H}_{3}-15$, but not with $\mathrm{H}-10$, revealing that $\mathrm{H}-14$ was $\beta$-oriented. $\mathrm{H}-12$ correlated with each of the $\mathrm{C}-13$ methylene protons and $\mathrm{H}_{3}-20$, but not with $\mathrm{H}-10$, indicating that $\mathrm{H}-12$ was $\beta$-oriented and was positioned on the equatorial direction in the cyclohexane ring by modeling analysis. H-17 exhibited correlations with H-9 and H-7 and was also found to be reasonably close to H-9 and H-7 by modeling analysis; thus, $\mathrm{H}-17$ could therefore be placed on the $\beta$ face in 1 , and $\mathrm{H}-7$ was $\beta$-oriented. One of the C-3 methylene protons $\left(\delta_{\mathrm{H}} 3.73\right)$ displayed a correlation with $\mathrm{H}_{3}-15$; therefore, it was assigned as the $\mathrm{H}-3 \beta$ proton, and the other was assigned as $\mathrm{H}-3 \alpha\left(\delta_{\mathrm{H}} 1.46\right)$. $\mathrm{H}-6$ displayed correlations with $\mathrm{H}-3 \beta$ and $\mathrm{H}-7$, which confirmed that this proton was in the $\beta$-orientation, and the oxygen bridge between $C-4$ and $C-8$ was 
found to be $\alpha$-oriented by modeling analysis. Based on the aforementioned results, the structure, including the relative configuration, of $\mathbf{1}$ was elucidated unambiguously.

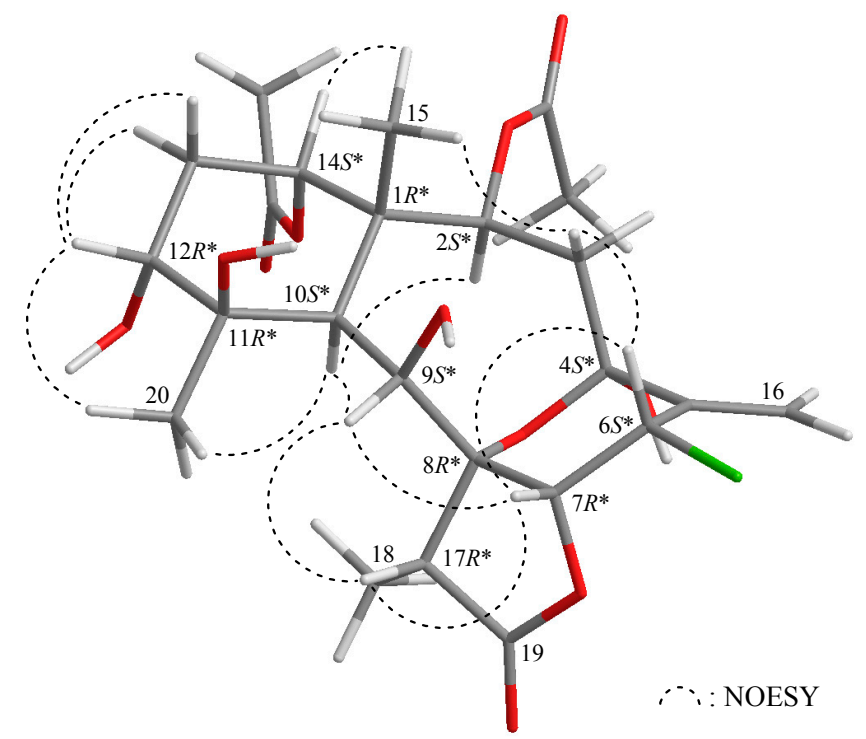

Figure 2. Selected protons with key nuclear Overhauser effect spectroscopy (NOESY) correlations of $\mathbf{1}$.

Briarenolide ZII (2) was isolated as a white powder and had a molecular formula of $\mathrm{C}_{28} \mathrm{H}_{38} \mathrm{O}_{10}$ on the basis of HRESIMS at $m / z 557.23552$ (calcd. for $\mathrm{C}_{28} \mathrm{H}_{38} \mathrm{O}_{10}+\mathrm{Na}$, 557.23572). Carbonyl resonances in the ${ }^{13} \mathrm{C}$ NMR spectrum of 2 (Table 2) at $\delta_{C} 173.0,170.7,170.4$ and 169.9 demonstrated the presence of a $\gamma$-lactone and three other esters in 2. It was found that the NMR signals of $\mathbf{2}$ were similar to those of a known briarane analogue, excavatolide F (7) [7] (Figure 1), except that the signals corresponding to the 9 -acetoxy group in $\mathbf{7}$ were replaced by signals for a hydroxy group in $\mathbf{2}$. The correlations from a NOESY experiment of $\mathbf{2}$ also revealed that the stereochemistry of this metabolite was identical to that of 7. Thus, briarenolide ZII (2) was found to be the 9-O-deacetyl derivative of 7.

Briarenolide ZIII (3) had a molecular formula $\mathrm{C}_{24} \mathrm{H}_{32} \mathrm{O}_{10}$ as deduced from HRESIMS at $\mathrm{m} / z$ 503.18858 (calcd. for $\mathrm{C}_{24} \mathrm{H}_{32} \mathrm{O}_{10}+\mathrm{Na}, 503.18877$ ). The IR spectrum of 1 showed three bands at 3444, 1779 and $1732 \mathrm{~cm}^{-1}$, which were in agreement with the presence of hydroxy, $\gamma$-lactone and ester groups. Carbonyl resonances in the ${ }^{13} \mathrm{C}$ NMR spectrum of 3 at $\delta_{C} 171.8,170.7$ and 170.6 revealed the presence of a $\gamma$-lactone and two esters (Table 3). Both esters were identified as acetates by the presence of two acetyl methyl resonances in the ${ }^{1} \mathrm{H}\left(\delta_{\mathrm{H}} 2.01,1.98\right.$, each $\left.3 \mathrm{H} \times \mathrm{s}\right)$ and ${ }^{13} \mathrm{C}\left(\delta_{\mathrm{C}} 21.1,21.1\right) \mathrm{NMR}$ spectra (Table 3).

It was found that the NMR data of 3 were similar to those of a known briarane analogue, $2 \beta$-acetoxy-2-(debutyryloxy)-stecholide E (8) [1] (Figure 1), except that the signals corresponding to the 4-hydroxy group in 3 were not present in $\mathbf{8}$. A correlation from the NOESY signals of $\mathbf{3}$ showed that $\mathrm{H}-4$ correlated with $\mathrm{H}-2$, but not with $\mathrm{H}_{3}-15$, indicating that the hydroxy group at $\mathrm{C}-4$ was $\beta$-oriented. The results of ${ }^{1} \mathrm{H}-{ }^{1} \mathrm{H}$ COSY and $\mathrm{HMBC}$ correlations fully supported the positions of functional groups, and hence, briarenolide ZIII (3) was found to be the $4 \beta$-hydroxy derivative of 8 . 
Table 2. ${ }^{1} \mathrm{H}\left(400 \mathrm{MHz}, \mathrm{CDCl}_{3}\right)$ and ${ }^{13} \mathrm{C}\left(100 \mathrm{MHz}, \mathrm{CDCl}_{3}\right)$ NMR data and ${ }^{1} \mathrm{H}-{ }^{1} \mathrm{H}$ COSY and HMBC correlations for briarane 2 .

\begin{tabular}{|c|c|c|c|c|}
\hline Position & $\delta_{\mathbf{H}}(J$ in $\mathbf{H z})$ & $\begin{array}{c}\delta_{C} \\
\text { Multiple }\end{array}$ & ${ }^{1} \mathrm{H}-{ }^{1} \mathrm{H}$ COSY & НМВС \\
\hline 1 & - & $45.6, \mathrm{C}$ & - & - \\
\hline 3 & $5.76 \mathrm{dd}(16.0,10.0)$ & $126.0, \mathrm{CH}$ & H-2, H-4 & C -5 \\
\hline 4 & $6.82 \mathrm{~d}(16.0)$ & 139.0, $\mathrm{CH}$ & $\mathrm{H}-3, \mathrm{H}-6, \mathrm{H}_{3}-16$ & $C-2,-3,-5,-6$ \\
\hline 5 & - & $140.4, \mathrm{C}$ & - & - \\
\hline 8 & - & $69.9, \mathrm{C}$ & - & - \\
\hline 9 & $4.36 \mathrm{~d}(9.6)$ & $74.6, \mathrm{CH}$ & $\mathrm{H}-10$ & $C-1,-8,-10,-11,-17$ \\
\hline 10 & $2.08 \mathrm{~d}(4.8)$ & $38.5, \mathrm{CH}$ & H-9, H-11 & $C-1,-2,-8,-9,-11,-14,-15,-20$ \\
\hline 11 & $2.23 \mathrm{~m}$ & $39.2, \mathrm{CH}$ & $\mathrm{H}-10, \mathrm{H}-12, \mathrm{H}_{3}-20$ & $C-1,-10,-12,-13,-20$ \\
\hline 12 & $4.98 \mathrm{~m}$ & $70.3, \mathrm{CH}$ & $\mathrm{H}-11, \mathrm{H}_{2}-13$ & $\mathrm{C}-20,-1^{\prime}$ \\
\hline 17 & - & $63.4, \mathrm{C}$ & $\mathrm{H}_{3}-18$ & - \\
\hline 18 & $1.52 \mathrm{~s}$ & $10.0, \mathrm{CH}_{3}$ & $\mathrm{H}-17$ & $C-7,-8,-19$ \\
\hline 19 & - & $170.7, \mathrm{C}$ & - & - \\
\hline 20 & $1.15 \mathrm{~d}(7.2)$ & $10.5, \mathrm{CH}_{3}$ & $\mathrm{H}-11$ & $C-10,-11,-12$ \\
\hline \multirow[t]{2}{*}{ OAc-2 } & - & $169.9, \mathrm{C}$ & - & - \\
\hline & $1.98 \mathrm{~s}$ & 21.2, $\mathrm{CH}_{3}$ & - & Acetate carbonyl \\
\hline \multirow[t]{2}{*}{ OAc-14 } & - & $170.4, \mathrm{C}$ & - & - \\
\hline & $2.09 \mathrm{~s}$ & 21.3, $\mathrm{CH}_{3}$ & - & Acetate carbonyl \\
\hline $\mathrm{OC}(\mathrm{O}) \operatorname{Pr}-121^{\prime} 2^{\prime} 3^{\prime} 4^{\prime}$ & - & - & - & - \\
\hline $1^{\prime}$ & - & 173.0, C & - & - \\
\hline $2^{\prime}$ & 2.26 t $(7.2)$ & 36.3, $\mathrm{CH}_{2}$ & $\mathrm{H}_{2}-3^{\prime}$ & $C-1^{\prime},-3^{\prime},-4^{\prime}$ \\
\hline
\end{tabular}

Table 3. ${ }^{1} \mathrm{H}\left(400 \mathrm{MHz}, \mathrm{CDCl}_{3}\right)$ and ${ }^{13} \mathrm{C}\left(100 \mathrm{MHz}, \mathrm{CDCl}_{3}\right) \mathrm{NMR}$ data and ${ }^{1} \mathrm{H}-{ }^{1} \mathrm{H}$ COSY and HMBC correlations for briarane 3 .

\begin{tabular}{|c|c|c|c|c|}
\hline Position & $\delta_{\mathrm{H}}(J$ in $\mathrm{Hz})$ & $\delta_{C}$, Multiple & ${ }^{1} \mathbf{H}-{ }^{1} \mathbf{H}$ COSY & НМВС \\
\hline 1 & - & $45.7, \mathrm{C}$ & - & - \\
\hline 2 & $4.72 \mathrm{~d}(6.0)$ & $73.8, \mathrm{CH}$ & $\mathrm{H}_{2}-3$ & C-1, $-4,-10,-14,-15$, acetate carbonyl \\
\hline 3 & $3.05 \mathrm{~m} ; 1.92 \mathrm{~m}$ & $40.8, \mathrm{CH}_{2}$ & $\mathrm{H}-2, \mathrm{H}-4$ & $C-1,-4,-5$ \\
\hline 4 & $4.23 \mathrm{dd}(12.4,5.2)$ & $71.3, \mathrm{CH}$ & $\mathrm{H}_{2}-3$ & $C-5,-6,-16$ \\
\hline 5 & - & $147.5, \mathrm{C}$ & - & - \\
\hline 6 & $5.49 \mathrm{dt}(9.6,1.2)$ & $122.0, \mathrm{CH}$ & $\mathrm{H}-7, \mathrm{H}_{3}-16$ & $C-4,-16$ \\
\hline 7 & $6.22 \mathrm{~d}(9.6)$ & $73.4, \mathrm{CH}$ & H-6 & $C-5,-6$ \\
\hline 8 & - & $71.0, \mathrm{C}$ & - & - \\
\hline 9 & $4.45 \mathrm{dd}(6.0,3.6)$ & $72.2, \mathrm{CH}$ & $\mathrm{H}-10, \mathrm{OH}-9$ & $C-7,-8,-11$ \\
\hline 10 & $2.29 \mathrm{~d}(3.6)$ & $42.5, \mathrm{CH}$ & H-9 & $C-1,-8,-9,-11,-15$ \\
\hline 11 & - & $63.6, \mathrm{C}$ & - & - \\
\hline 12 & $3.05 \mathrm{~d}(2.8)$ & $61.4, \mathrm{CH}$ & $\mathrm{H}_{2}-13$ & n. o. ${ }^{a}$ \\
\hline 13 & $2.08 \mathrm{~m}$ & $25.2, \mathrm{CH}_{2}$ & $\mathrm{H}-12, \mathrm{H}-14$ & n. o. \\
\hline 14 & 4.73 br s & $73.8, \mathrm{CH}$ & $\mathrm{H}_{2}-13$ & C-1, $-2,-10,-12,-15$, acetate carbonyl \\
\hline 15 & $1.19 \mathrm{~s}$ & $16.0, \mathrm{CH}_{3}$ & - & $C-1,-10,-14$ \\
\hline 16 & $2.11 \mathrm{~d}(1.2)$ & $25.5, \mathrm{CH}_{3}$ & H-6 & $C-4,-5,-6$ \\
\hline 17 & - & $62.5, \mathrm{C}$ & - & - \\
\hline 18 & $1.67 \mathrm{~s}$ & $9.4, \mathrm{CH}_{3}$ & - & $C-8,-17,-19$ \\
\hline 19 & - & $171.8, \mathrm{C}$ & - & - \\
\hline 20 & $1.35 \mathrm{~s}$ & $24.5, \mathrm{CH}_{3}$ & - & $C-10,-11,-12$ \\
\hline \multirow[t]{2}{*}{ OAc-2 } & - & $170.7, \mathrm{C}$ & - & - \\
\hline & $1.98 \mathrm{~s}$ & $21.1, \mathrm{CH}_{3}$ & - & Acetate carbonyl \\
\hline \multirow[t]{2}{*}{ OAc-14 } & - & $170.6, \mathrm{C}$ & - & - \\
\hline & $2.01 \mathrm{~s}$ & $21.1, \mathrm{CH}_{3}$ & - & Acetate carbonyl \\
\hline $\mathrm{OH}-19$ & $2.89 \mathrm{~d}(6.0)$ & - & $\mathrm{H}-9$ & C-8 \\
\hline
\end{tabular}


Briarenolide ZIV (4) was obtained as a white powder, and the molecular formula of 4 was determined to be $\mathrm{C}_{28} \mathrm{H}_{40} \mathrm{O}_{11}$ (9 $9^{\circ}$ of unsaturation) by HRESIMS at $m / z 575.24645$ (calcd. for $\mathrm{C}_{28} \mathrm{H}_{40} \mathrm{O}_{11}$ $+\mathrm{Na}, 575.24628$ ). The IR spectrum of 4 showed three bands at 3444,1778 and $1732 \mathrm{~cm}^{-1}$, consistent with the presence of hydroxy, $\gamma$-lactone and ester carbonyl groups. Carbonyl resonances in the ${ }^{13} \mathrm{C}$ NMR spectrum of 4 showed signals at $\delta_{C} 173.9,173.2,170.8$ and 170.4 , which revealed the presence of a $\gamma$-lactone and three esters in 4 (Table 4), of which, two of the esters were identified as acetates based on the presence of two acetyl methyl resonances in the ${ }^{1} \mathrm{H}$ NMR spectrum of 4 at $\delta_{\mathrm{H}} 1.97$ $(2 \times 3 \mathrm{H}, \mathrm{s})($ Table 4$)$. The other ester was found to be an $n$-butyrate group based on ${ }^{1} \mathrm{H}$ NMR studies, which revealed seven contiguous protons $\left(\delta_{\mathrm{H}} 0.94,3 \mathrm{H}, \mathrm{t}, J=7.2 \mathrm{~Hz} ; 1.65,2 \mathrm{H}\right.$, sextet, $J=7.2 \mathrm{~Hz} ; 2.23$, $2 \mathrm{H}, \mathrm{t}, J=7.2 \mathrm{~Hz}$ ). According to the ${ }^{1} \mathrm{H}$ and ${ }^{13} \mathrm{C}$ NMR spectra, 4 was found to have a $\gamma$-lactone moiety $\left(\delta_{\mathrm{C}} 173.9, \mathrm{C}-19\right)$ and a trisubstituted olefin $\left(\delta_{\mathrm{C}} 145.4, \mathrm{C}-5 ; 121.6, \mathrm{CH}-6 ; \delta_{\mathrm{H}} 5.32,1 \mathrm{H}, \mathrm{d}, J=8.8 \mathrm{~Hz}\right.$, $\mathrm{H}-6)$. The presence of a tetrasubstituted epoxide that contained a methyl substituent was established based on the signals of two oxygenated quaternary carbons at $\delta_{\mathrm{C}} 71.8(\mathrm{C}-8)$ and $63.7(\mathrm{C}-17)$ and confirmed by the proton signals of a methyl singlet at $\delta_{\mathrm{H}} 1.51\left(3 \mathrm{H}, \mathrm{s}, \mathrm{H}_{3}-18\right)$. Thus, from the NMR data, five degrees of unsaturation were accounted for, and 4 was identified as a tetracyclic compound. From the ${ }^{1} \mathrm{H}-{ }^{1} \mathrm{H}$ COSY spectrum of 4 (Table 4), three different structural units, including C-2/-3/-4, C-6/-7 and C-9/-10/-11/-12/-13/-14, were identified. From these data and the HMBC correlation results (Table 4), the connectivity from C-1 to C-14 could be established. A methyl attached at C-5 was confirmed by an allylic coupling between $\mathrm{H}_{3}-16 / \mathrm{H}-6$ and by the HMBC correlations between $\mathrm{H}_{3}-16 / \mathrm{C}-4,-5$ and -6 . The $\mathrm{C}-15$ and $\mathrm{C}-20$ methyl groups were identified as being positioned at $\mathrm{C}-1$ and $\mathrm{C}-11$ from the HMBC correlations between $\mathrm{H}_{3}-15 / \mathrm{C}-1,-2,-10,-14$ and $\mathrm{H}_{3}-20 / \mathrm{C}-10,-11,-12$, respectively. Furthermore, the acetate esters positioned at $\mathrm{C}-2$ and $\mathrm{C}-14$ were established by the HMBC correlations between $\delta_{\mathrm{H}} 4.97(\mathrm{H}-2)$ and $4.70(\mathrm{H}-14)$ and the acetate carbonyls at $\delta_{\mathrm{C}} 170.4$ and 170.8 , respectively. The location of an $n$-butyrate group in 4 was verified by an HMBC correlation between H-12 $\left(\delta_{\mathrm{H}} 4.83\right)$ and the n-butyrate carbonyl carbon $\left(\delta_{\mathrm{C}}\right.$ 173.2) (Table 4). These data, together with the HMBC correlations between $\mathrm{H}_{3}-18 / \mathrm{C}-8,-17$ and -19 , established the main molecular framework of 4 . The NMR data of 4 were found to be similar to those of a known briarane, excavatolide Z (9) [8] (Figure 1), except that the signals corresponding to the 4-hydroxy group in 4 were not present in $\mathbf{9}$, and an $11 \beta$-hydroxy group was found in $\mathbf{9}$. The correlations from NOESY signals of 4 (Figure 3) also showed that the relative configurations of most chiral centers of 4 were similar to those of 9 . H-10 exhibited interactions with $\mathrm{H}-2$ and $\mathrm{H}-11$, and $\mathrm{H}-2$ correlated with $\mathrm{H}-4$, indicating that the hydroxy group at $C-4$ and the methyl group at $C$ - 11 were $\beta$-oriented; additionally, briarenolide ZIV (4) was found to be the $4 \beta$-hydroxy-11-dehydroxy-11 $\beta$-methyl derivative of 9 .

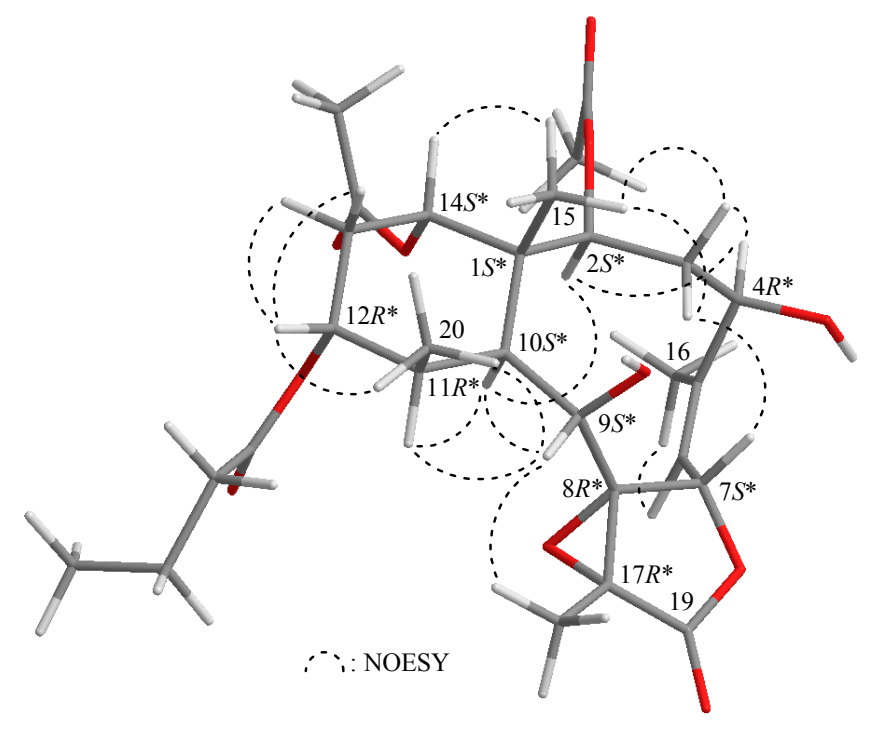

Figure 3. Selected protons with key NOESY correlations of 4. 
Table 4. ${ }^{1} \mathrm{H}\left(400 \mathrm{MHz}, \mathrm{CDCl}_{3}\right)$ and ${ }^{13} \mathrm{C}\left(100 \mathrm{MHz}, \mathrm{CDCl}_{3}\right)$ NMR data and ${ }^{1} \mathrm{H}-{ }^{1} \mathrm{H}$ COSY and HMBC correlations for briarane 4 .

\begin{tabular}{|c|c|c|c|c|}
\hline Position & $\delta_{\mathrm{H}}(J$ in $\mathrm{Hz})$ & $\delta_{C}$, Multiple & ${ }^{1} \mathrm{H}-{ }^{1} \mathrm{H}$ COSY & НМBC \\
\hline 1 & - & $46.1, \mathrm{C}$ & - & - \\
\hline 2 & $4.97 \mathrm{~d}(8.0)$ & $74.9, \mathrm{CH}$ & $\mathrm{H}_{2}-3$ & C-1, $-4,-10,-15$, acetate carbonyl \\
\hline 3 & $3.22 \mathrm{dd}(15.2,12.0) ; 1.93 \mathrm{~m}$ & $39.7, \mathrm{CH}_{2}$ & $\mathrm{H}-2, \mathrm{H}-4$ & $C-1,-4$ \\
\hline 4 & $4.16 \mathrm{dd}(12.0,5.2)$ & $71.3, \mathrm{CH}$ & $\mathrm{H}_{2}-3$ & $C-3,-5,-6,-16$ \\
\hline 5 & - & $145.4, \mathrm{C}$ & - & - \\
\hline 6 & $5.32 \mathrm{~d}(8.8)$ & 121.6, $\mathrm{CH}$ & $\mathrm{H}-7, \mathrm{H}_{3}-16$ & $C-4,-16$ \\
\hline 7 & $6.14 \mathrm{~d}(8.8)$ & $75.4, \mathrm{CH}$ & H-6 & $C-5,-6,-19$ \\
\hline 8 & - & $71.8, \mathrm{C}$ & - & - \\
\hline 9 & 3.79 br s & $74.1, \mathrm{CH}$ & $\mathrm{H}-10$ & $C-1,-7,-8,-10,-11,-17$ \\
\hline 10 & $2.39 \mathrm{~d}(5.2)$ & $37.2, \mathrm{CH}$ & H-9, H-11 & $C-1,-2,-8,-9,-11,-12,-14,-15,-20$ \\
\hline 11 & $1.88 \mathrm{~m}$ & $43.2, \mathrm{CH}$ & $\mathrm{H}-10, \mathrm{H}-12, \mathrm{H}_{3}-20$ & $C-1,-10,-12,-20$ \\
\hline 12 & $4.83 \mathrm{br} \mathrm{s}$ & $72.1, \mathrm{CH}$ & $\mathrm{H}-11, \mathrm{H}_{2}-13$ & C- $-10,-14,-1^{\prime}$ \\
\hline 13 & $2.11 \mathrm{~m} ; 1.95 \mathrm{~m}$ & $24.6, \mathrm{CH}_{2}$ & $\mathrm{H}-12, \mathrm{H}-14$ & C $-11,-12,-14$ \\
\hline 14 & $4.70 \mathrm{br} \mathrm{s}$ & $74.2, \mathrm{CH}$ & $\mathrm{H}_{2}-13$ & $C-1,-2,-10,-12,-15$, acetate carbonyl \\
\hline 15 & $1.32 \mathrm{~s}$ & $15.2, \mathrm{CH}_{3}$ & - & $C-1,-2,-10,-14$ \\
\hline 16 & $2.05 \mathrm{~d}(1.2)$ & $25.3, \mathrm{CH}_{3}$ & H-6 & $C-4,-5,-6$ \\
\hline 17 & - & $63.7, \mathrm{C}$ & - & - \\
\hline 18 & $1.51 \mathrm{~s}$ & 9.7, $\mathrm{CH}_{3}$ & - & $C-8,-17,-19$ \\
\hline 19 & - & $173.9, \mathrm{C}$ & - & - \\
\hline 20 & $1.25 \mathrm{~d}(7.2)$ & $15.2, \mathrm{CH}_{3}$ & $\mathrm{H}-11$ & $C-10,-11,-12$ \\
\hline \multirow[t]{2}{*}{ OAc-12 } & - & $170.4, \mathrm{C}$ & - & - \\
\hline & $1.97 \mathrm{~s}$ & $21.2, \mathrm{CH}_{3}$ & - & Acetate carbonyl \\
\hline \multirow[t]{2}{*}{ OAc-14 } & - & $170.8, \mathrm{C}$ & - & - \\
\hline & $1.97 \mathrm{~s}$ & $21.5, \mathrm{CH}_{3}$ & - & Acetate carbonyl \\
\hline $\begin{array}{l}\mathrm{OC}(\mathrm{O}) \mathrm{Pr}-12 \\
1^{\prime} 2^{\prime} 3^{\prime} 4^{\prime}\end{array}$ & - & - & - & - \\
\hline $1^{\prime}$ & - & 173.2, C & & - \\
\hline $2^{\prime}$ & $2.23 \mathrm{t}(7.2)$ & $36.6, \mathrm{CH}_{2}$ & $\mathrm{H}_{2}-3^{\prime}$ & $C-1^{\prime},-3^{\prime},-4^{\prime}$ \\
\hline $3^{\prime}$ & $1.65 \operatorname{sext}(7.2)$ & $18.5, \mathrm{CH}_{2}$ & $\mathrm{H}_{2}-2^{\prime}, \mathrm{H}_{3}-4^{\prime}$ & $C-1^{\prime},-2^{\prime},-4^{\prime}$ \\
\hline $4^{\prime}$ & $0.94 \mathrm{t}(7.2)$ & 13.6, $\mathrm{CH}_{3}$ & $\mathrm{H}_{2}-3^{\prime}$ & $C-2^{\prime},-3^{\prime}$ \\
\hline
\end{tabular}

Briarenolide ZV (5) was obtained as a white powder and had the molecular formula $\mathrm{C}_{24} \mathrm{H}_{30} \mathrm{O}_{10}$, as determined by HRESIMS at $m / z 505.20460$ (calcd. for $\mathrm{C}_{24} \mathrm{H}_{30} \mathrm{O}_{10}+\mathrm{Na}$, 505.20442) $\left(10^{\circ}\right.$ of unsaturation). The IR spectrum of 5 showed bands at 3445,1770 and $1732 \mathrm{~cm}^{-1}$, consistent with the presence of hydroxy, $\gamma$-lactone and ester carbonyl groups. Comparison of the ${ }^{1} \mathrm{H}$ and distortioneless enhancement by polar transfer (DEPT) spectra with the molecular formula revealed that there must be three exchangeable protons, requiring the presence of three hydroxy groups. In addition, it was found that the spectral data (IR, ${ }^{1} \mathrm{H}$ and ${ }^{13} \mathrm{C}$ NMR) of 5 (Table 5) were similar to those of a known briarane, excavatolide Z (9) [8] (Figure 1), except that 9 exhibited signals representing an $n$-butyrate substitution, which were replaced by a hydroxy group in 5. The results of ${ }^{1} \mathrm{H}-{ }^{1} \mathrm{H}$ COSY and HMBC correlations fully supported the positions of functional groups, and hence, briarenolide ZV (5) was found to be the 12-O-debutyryl derivative of 9 .

The new briarane, briarenolide ZVI (6), had a molecular formula of $\mathrm{C}_{26} \mathrm{H}_{36} \mathrm{O}_{11}$ as determined by HRESIMS at $m / z 547.21473$ (calcd. for $\mathrm{C}_{26} \mathrm{H}_{36} \mathrm{O}_{11}+\mathrm{Na}, 547.21498$ ). Thus, nine degrees of unsaturation were therefore determined for the molecule of 6 . In addition, the spectral data (IR, ${ }^{1} \mathrm{H}$ and $\left.{ }^{13} \mathrm{C} \mathrm{NMR}\right)$ (Table 6) of 6 were found to be similar to those of a known briarane, excavatolide E (10) [9] (Figure 1). However, the NMR spectra revealed that the signals representing the C-4 methylene group in 10 were replaced by those of an additional acetoxy group. In the NOESY experiment of 6, H-10 gives correlations to $\mathrm{H}-2, \mathrm{H}-9, \mathrm{H}-11$ and $\mathrm{H}-12$, but not to $\mathrm{H}_{3}-15$ and $\mathrm{H}_{3}-20$, and $\mathrm{H}-2$ was found to show a correlation with $\mathrm{H}-4$, indicating that these protons $(\mathrm{H}-2, \mathrm{H}-4, \mathrm{H}-9, \mathrm{H}-10, \mathrm{H}-11$ and $\mathrm{H}-12)$ are located on the same face of the molecule and assigned as $\alpha$-protons, since the $\mathrm{C}-15$ and $\mathrm{C}-20$ methyls are the $\beta$-substituents at $\mathrm{C}-1$ and $\mathrm{C}-11$, respectively. The signal of $\mathrm{H}_{3}-20$ showed a correlation with $\mathrm{H}_{3}-18$, indicating that $\mathrm{H}_{3}-18$ and 8,17-epoxide group were $\beta$ - and $\alpha$-oriented, respectively, in the $\gamma$-lactone ring in 6. $\mathrm{H}-4$ correlated with $\mathrm{H}-2$, but not with $\mathrm{H}-7$ and $\mathrm{H}_{3}-15$, indicating that $\mathrm{H}-7$ was $\beta$-oriented. $\mathrm{H}-14$ was found to exhibit nuclear Overhauser effect (NOE) responses with $\mathrm{H}-2$ and $\mathrm{H}_{3}-15$, but not with 
H-10, revealing the $\beta$-orientation of this proton. Thus, based on the above findings, Compound 6 was found to be the $4 \beta$-acetoxy derivative of 10, with a structure as described by Formula 6 . Furthermore, the chemical shifts for $\mathrm{H}_{3}-18$ in briaranes 4,5 and 6 were found to appear at $\delta_{\mathrm{H}} 1.51,1.68$ and 1.57, respectively, indicating that the $11 \beta$-hydroxy group in 5 led to a downfield chemical shift for $\mathrm{H}_{3}-18$.

Table 5. ${ }^{1} \mathrm{H}\left(400 \mathrm{MHz}, \mathrm{CDCl}_{3}\right)$ and ${ }^{13} \mathrm{C}\left(100 \mathrm{MHz}, \mathrm{CDCl}_{3}\right) \mathrm{NMR}$ data and ${ }^{1} \mathrm{H}-{ }^{1} \mathrm{H}$ COSY and HMBC correlations for briarane 5 .

\begin{tabular}{|c|c|c|c|c|}
\hline Position & $\delta_{\mathrm{H}}(J$ in $\mathrm{Hz})$ & $\delta_{C}$, Multiple & ${ }^{1} \mathrm{H}-{ }^{1} \mathrm{H}$ COSY & НМВС \\
\hline 1 & - & $48.6, \mathrm{C}$ & - & - \\
\hline 2 & $5.02 \mathrm{~d}(7.2)$ & $75.7, \mathrm{CH}$ & $\mathrm{H}_{2}-3$ & $C-1,-3,-4,-10,-14,-15$, acetate carbonyl \\
\hline 3 & $2.86 \mathrm{td}(15.2,5.2) ; 1.59 \mathrm{~m}$ & $32.5, \mathrm{CH}_{2}$ & $\mathrm{H}-2, \mathrm{H}_{2}-4$ & n. o. ${ }^{\text {a }}$ \\
\hline 4 & $2.50 \mathrm{br} \mathrm{d}(15.2) ; 1.91 \mathrm{~m}$ & $28.7, \mathrm{CH}_{2}$ & $\mathrm{H}_{2}-3$ & n. o. \\
\hline 5 & - & $146.0, \mathrm{C}$ & - & - \\
\hline 6 & $5.28 \mathrm{~d}(9.6)$ & $117.9, \mathrm{CH}$ & $\mathrm{H}-7, \mathrm{H}_{3}-16$ & $C-4$ \\
\hline 7 & $5.50 \mathrm{~d}(9.6)$ & $75.1, \mathrm{CH}$ & H-6 & $C-5$ \\
\hline 8 & - & $71.1, \mathrm{C}$ & - & - \\
\hline 9 & $4.65 \mathrm{dd}(5.6,2.0)$ & $69.7, \mathrm{CH}$ & $\mathrm{H}-10, \mathrm{OH}-9$ & $C-7,-8,-10,-11,-17$ \\
\hline 10 & $2.13 \mathrm{br} \mathrm{s}$ & $44.0, \mathrm{CH}$ & H-9 & C-9 \\
\hline 11 & - & 78.6, C & - & - \\
\hline 12 & $3.43 \mathrm{brd}(10.0)$ & $76.6, \mathrm{CH}$ & $\mathrm{H}_{2}-13, \mathrm{OH}-12$ & n. o. \\
\hline 13 & $2.32 \mathrm{~m} ; 1.92 \mathrm{~m}$ & $26.5, \mathrm{CH}_{2}$ & H-12, H-14 & n. o. \\
\hline 14 & $4.99 \mathrm{t}(2.8)$ & $77.5, \mathrm{CH}$ & $\mathrm{H}_{2}-13$ & $C-1,-10,-15$, acetate carbonyl \\
\hline 15 & $1.42 \mathrm{~s}$ & $15.9, \mathrm{CH}_{3}$ & - & $C-1,-2,-10,-14$ \\
\hline 16 & $2.00 \mathrm{~s}$ & $26.9, \mathrm{CH}_{3}$ & H-6 & $C-4,-5,-6$ \\
\hline 17 & - & $63.4, \mathrm{C}$ & - & - \\
\hline 18 & $1.68 \mathrm{~s}$ & $9.6, \mathrm{CH}_{3}$ & - & $C-8,-17,-19$ \\
\hline 19 & - & $171.6, \mathrm{C}$ & - & \\
\hline 20 & $1.41 \mathrm{~s}$ & $31.1, \mathrm{CH}_{3}$ & - & $C-10,-11,-12$ \\
\hline \multirow[t]{2}{*}{ OAc-2 } & - & $170.8, \mathrm{C}$ & - & - \\
\hline & $1.99 \mathrm{~s}$ & $21.4, \mathrm{CH}_{3}$ & - & Acetate carbonyl \\
\hline \multirow[t]{2}{*}{ OAc-14 } & - & $169.8, \mathrm{C}$ & - & - \\
\hline & $2.03 \mathrm{~s}$ & 21.7, $\mathrm{CH}_{3}$ & - & Acetate carbonyl \\
\hline $\mathrm{OH}-9$ & $2.45 \mathrm{br} \mathrm{s}$ & - & H-9 & n. o. \\
\hline $\mathrm{OH}-12$ & $2.74 \mathrm{~d}(10.0)$ & - & $\mathrm{H}-12$ & n. o. \\
\hline
\end{tabular}

In an in vitro anti-inflammatory activity assay, Western blot analysis was used to evaluate the upregulation of the pro-inflammatory cyclooxygenase 2 (COX-2) and inducible nitric oxide synthase (iNOS) protein expressions in lipopolysaccharide (LPS)-stimulated RAW264.7 macrophage cells. At a concentration of $10 \mu \mathrm{M}$, briarenolides ZII (2) and ZVI (6) were found to significantly reduce the levels of iNOS to $47.2 \%$ and $55.7 \%$, respectively, in comparison to the control cells stimulated with LPS only (Figure 4 and Table 7). By using trypan blue staining, it was observed that briarenolides ZI-ZVI (1-6) did not induce significant cytotoxicity in RAW264.7 macrophage cells. 
Table 6. ${ }^{1} \mathrm{H}\left(400 \mathrm{MHz}, \mathrm{CDCl}_{3}\right)$ and ${ }^{13} \mathrm{C}\left(100 \mathrm{MHz}, \mathrm{CDCl}_{3}\right)$ NMR data and ${ }^{1} \mathrm{H}-{ }^{1} \mathrm{H}$ COSY and HMBC correlations for briarane 6 .

\begin{tabular}{|c|c|c|c|c|}
\hline Position & $\delta_{\mathrm{H}}(J$ in $\mathrm{Hz})$ & $\delta_{C}$, Multiple & ${ }^{1} \mathrm{H}-{ }^{1} \mathrm{H}$ COSY & НМВС \\
\hline 1 & - & $46.1, \mathrm{C}$ & - & - \\
\hline 2 & $4.87 \mathrm{~d}(8.0)$ & $73.6, \mathrm{CH}$ & $\mathrm{H}_{2}-3$ & $C-1,-3,-4,-10,-14,-15$, acetate carbonyl \\
\hline 3 & $3.16 \mathrm{dd}(15.6,12.8) ; 1.91 \mathrm{~m}$ & $37.6, \mathrm{CH}_{2}$ & $\mathrm{H}-2, \mathrm{H}-4$ & $C-1,-2,-4,-5$ \\
\hline 4 & $5.01 \mathrm{dd}(12.8,5.6)$ & $72.7, \mathrm{CH}$ & $\mathrm{H}_{2}-3$ & $C-3,-5,-6,-16$, acetate carbonyl \\
\hline 5 & - & $144.1, \mathrm{C}$ & - & - \\
\hline 6 & $5.39 \mathrm{~d}(9.2)$ & $122.7, \mathrm{CH}$ & $\mathrm{H}-7, \mathrm{H}_{3}-16$ & $C-4,-16$ \\
\hline 7 & $5.92 \mathrm{~d}(9.2)$ & $74.5, \mathrm{CH}$ & H-6 & $C-5,-6,-19$ \\
\hline 8 & - & $71.7, \mathrm{C}$ & - & - \\
\hline 9 & $3.91 \mathrm{br} \mathrm{s}$ & $74.7, \mathrm{CH}$ & H-10, OH-9 & n. o. ${ }^{a}$ \\
\hline 10 & $2.20 \mathrm{dd}(4.8,2.2)$ & 41.6, $\mathrm{CH}$ & H-9, H-11 & $C-1,-2,-11,-15,-20$ \\
\hline 11 & $1.99 \mathrm{~m}$ & $44.7, \mathrm{CH}$ & $\mathrm{H}-10, \mathrm{H}-12, \mathrm{H}_{3}-20$ & n. o. \\
\hline 12 & $4.04 \mathrm{dt}(8.8,3.6)$ & $67.0, \mathrm{CH}$ & $\mathrm{H}-11, \mathrm{H}_{2}-13$ & n. o. \\
\hline 13 & $1.84 \mathrm{~m}$ & $29.0, \mathrm{CH}_{2}$ & $\mathrm{H}-12, \mathrm{H}-14$ & $\mathrm{C}-1,-12$ \\
\hline 14 & $4.78 \mathrm{t}(2.8)$ & $76.2, \mathrm{CH}$ & $\mathrm{H}_{2}-13$ & C- $-10,-12$, acetate carbonyl \\
\hline 15 & $1.31 \mathrm{~s}$ & $15.4, \mathrm{CH}_{3}$ & - & $C-1,-2,-10,-14$ \\
\hline 16 & $2.13 \mathrm{~s}$ & $25.3, \mathrm{CH}_{3}$ & H-6 & $C-4,-5,-6$ \\
\hline 17 & - & $63.3, \mathrm{C}$ & - & - \\
\hline 18 & $1.57 \mathrm{~s}$ & $10.2, \mathrm{CH}_{3}$ & - & $C-8,-17,-19$ \\
\hline 19 & - & $172.0, \mathrm{C}$ & - & - \\
\hline 20 & $1.19 \mathrm{~d}(7.2)$ & $9.5, \mathrm{CH}_{3}$ & $\mathrm{H}-11$ & $C-10,-11,-12$ \\
\hline \multirow[t]{2}{*}{ OAc-2 } & - & $170.2, \mathrm{C}$ & - & - \\
\hline & $1.99 \mathrm{~s}$ & $21.5, \mathrm{CH}_{3}$ & - & Acetate carbonyl \\
\hline \multirow[t]{2}{*}{ OAc-4 } & - & $170.4, \mathrm{C}$ & - & - \\
\hline & $2.01 \mathrm{~s}$ & 21.0, $\mathrm{CH}_{3}$ & - & Acetate carbonyl \\
\hline \multirow[t]{2}{*}{ OAc-14 } & - & $170.5, \mathrm{C}$ & - & - \\
\hline & $1.99 \mathrm{~s}$ & $21.2, \mathrm{CH}_{3}$ & - & Acetate carbonyl \\
\hline OH-9 & 2.95 br s & - & $\mathrm{H}-9$ & n. $o$. \\
\hline
\end{tabular}

${ }^{\mathrm{a}}$ n. o. $=$ not observed.

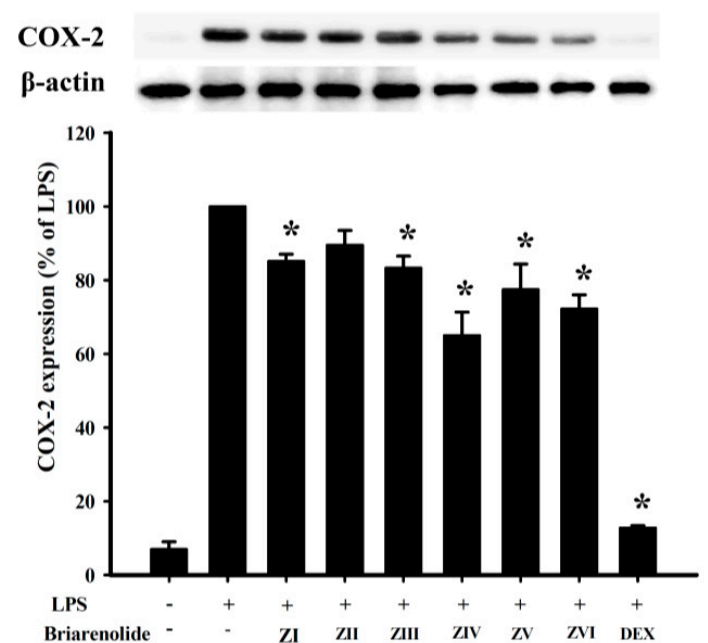

(A)

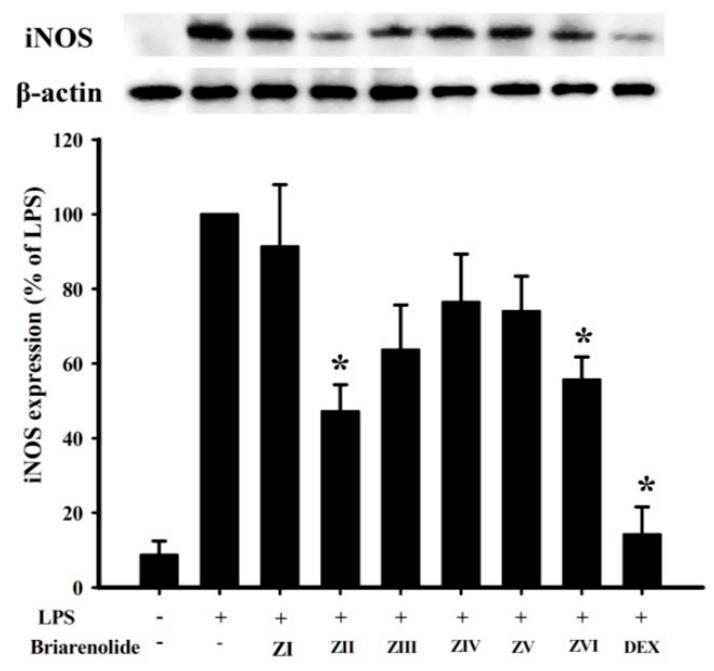

(B)

Figure 4. Effects of briarenolides ZI-ZVI (1-6) on pro-inflammatory cyclooxygenase 2 (COX-2) and inducible nitric oxide synthase (iNOS) protein expressions in lipopolysaccharide (LPS)-stimulated murine macrophage cell line RAW264.7. (A) Relative density of the COX-2 Western blot; (B) relative density of the iNOS Western blot. The relative intensity of the LPS-stimulated group was taken to be $100 \%$. Band intensities were quantified by densitometry and are indicated as the percentage change relative to that of the LPS-stimulated group. Briarenolides ZII (2) and ZVI (6) and DEX significantly inhibited LPS-induced iNOS protein expression $(<60 \%)$ in macrophages. The experiments were repeated three times ${ }^{*} p<0.05$, significantly different from the LPS-stimulated group). 
Table 7. The effect of briarenolides ZI-ZVI (1-6) on LPS-induced COX-2 and iNOS protein expression in macrophage.

\begin{tabular}{|c|c|c|}
\hline \multirow{2}{*}{ Compounds } & COX-2 & iNOS \\
\hline & Expression (\% of LPS) & Expression ( $\%$ of LPS) \\
\hline Control & $6.9 \pm 2.1$ & $8.7 \pm 3.8$ \\
\hline LPS & $100 \pm 0$ & $100 \pm 0$ \\
\hline ZI (1) & $85.1 \pm 1.9$ & $91.4 \pm 16.6$ \\
\hline ZII (2) & $89.5 \pm 4.0$ & $47.2 \pm 7.2$ \\
\hline ZIII (3) & $83.3 \pm 3.3$ & $63.7 \pm 12.0$ \\
\hline ZIV (4) & $65.0 \pm 6.4$ & $76.4 \pm 13.0$ \\
\hline ZV (5) & $77.5 \pm 6.9$ & $74.0 \pm 9.4$ \\
\hline ZVI (6) & $72.2 \pm 3.8$ & $55.7 \pm 6.1$ \\
\hline DEX ${ }^{a}$ & $12.8 \pm 0.6$ & $14.2 \pm 7.3$ \\
\hline
\end{tabular}

a Dexamethasone (DEX) was used as a positive control; COX-2: cyclooxygenase 2; iNOS: inducible nitric oxide synthase; LPS: liposaccharide.

\section{Experimental Section}

\subsection{General Experimental Procedures}

Melting points were determined using a Fargo apparatus (Panchum Scientific Corp. Kaohsiung, Taiwan), and the values were uncorrected. Optical rotation values were measured with a Jasco P-1010 digital polarimeter (Japan Spectroscopic Corporation, Tokyo, Japan). IR spectra were obtained with an FT-IR spectrophotometer (Digilab FTS 1000; Varian Inc., Palo Alto, CA, USA); peaks are reported in $\mathrm{cm}^{-1}$. NMR spectra were recorded on a 400-MHz Varian Mercury Plus NMR spectrometer (Varian Inc.) using the residual $\mathrm{CHCl}_{3}$ signal $\left(\delta_{\mathrm{H}} 7.26 \mathrm{ppm}\right)$ as the internal standard for ${ }^{1} \mathrm{H}$ NMR and $\mathrm{CDCl}_{3}\left(\delta_{\mathrm{C}} 77.1 \mathrm{ppm}\right)$ for ${ }^{13} \mathrm{C}$ NMR. Coupling constants $(J)$ are given in Hz. ESIMS and HRESIMS were recorded using a Bruker 7 Tesla solariX FTMS system (Bruker, Bremen, Germany). Column chromatography was performed using 230-400 mesh silica gel (Merck, Darmstadt, Germany). TLC was carried out on precoated $0.25 \mathrm{~mm}$-thick Kieselgel $60 \mathrm{~F}_{254}$ (Merck); spots were visualized by spraying with $10 \% \mathrm{H}_{2} \mathrm{SO}_{4}$ solution followed by heating. Normal-phase HPLC (NP-HPLC) was performed using a system equipped with a Hitachi L-7110 pump (Hitachi Ltd., Tokyo, Japan), a Hitachi L-7455 photodiode array detector and an injection port (7725; Rheodyne LLC, Rohnert Park, CA, USA). A semi-preparative normal-phase LiChrospher column (Hibar $250 \mathrm{~mm} \times 10 \mathrm{~mm}$, Si 60, $5 \mu \mathrm{m}$, Merck) was used for HPLC. Reverse-phase HPLC (RP-HPLC) was performed with a system equipped with a Hitachi L-7100 pump, a Hitachi L-2455 photodiode array detector, a Rheodyne 7725 injection port and a $25 \mathrm{~cm} \times 10 \mathrm{~mm}$ Polaris 5 C-18-A column (5 $\mu \mathrm{m}$; Varian Inc., Palo Alto, CA, USA).

\subsection{Animal Material}

Specimens of Briareum sp. were collected by hand by scuba divers in an area off the coast of southern Taiwan in July 2011 and stored in a freezer. A voucher specimen was deposited in the National Museum of Marine Biology \& Aquarium (NMMBA-TW-SC-2011-77) [10-14].

\subsection{Extraction and Isolation}

Sliced bodies of Briareum sp. (wet weight, $6.32 \mathrm{~kg}$; dry weight, $2.78 \mathrm{~kg}$ ) were extracted with a solvent mixture of methanol $(\mathrm{MeOH})$ and dichloromethane (DCM) (1:1). The extract was partitioned between ethyl acetate (EtOAc) and $\mathrm{H}_{2} \mathrm{O}$. The EtOAc layer was separated on silica gel followed by elution chromatography with a mixture of $n$-hexane/EtOAc (stepwise, 100:1, pure EtOAc) to yield 26 subfractions, A-Z. Fraction V was chromatographed on silica gel and eluted using a mixture of DCM/EtOAc (stepwise, 20:1, pure EtOAc) to afford 14 subfractions, V1-V14. Fraction V9 was separated by NP-HPLC using a mixture of DCM/EtOAc (1:1) to afford 25 subfractions, V9A-V9Y. Fraction V9J was further repurified by RP-HPLC, using a mixture of $\mathrm{MeOH} / \mathrm{H}_{2} \mathrm{O}$ (40:60) as the 
mobile phase to afford 1 (3.7 mg). Fractions $\mathrm{M}, \mathrm{N}, \mathrm{O}$ and $\mathrm{P}$ were combined and further separated on silica gel and eluted using n-hexane/EtOAc (stepwise, 4:1, pure EtOAc) to afford 30 subfractions, M1-M30. Fraction M4 was separated by NP-HPLC, using a mixture of DCM/acetone (40:1) to afford 17 subfractions, M4A-M4Q. Fraction M4B was purified by NP-HPLC, using a mixture of DCM/acetone (100:1) to afford 24 subfractions, M4B1-M4B24. Fraction M4B16 was further separated by RP-HPLC, using a mixture of $\mathrm{MeOH} / \mathrm{H}_{2} \mathrm{O}$ (stepwise, 30/70-70/30) to afford 2 (60:40, $1.7 \mathrm{mg}$ ). Fraction M12 was chromatographed by silica gel and eluted using a mixture of DCM/MeOH (stepwise, 100:1, pure $\mathrm{MeOH}$ ) to afford 34 subfractions, M12-1-M12-34. Fraction M12-31 was purified by RP-HPLC, using a mixture of $\mathrm{MeOH} / \mathrm{H}_{2} \mathrm{O}(60: 40)$ to afford $3(2.7 \mathrm{mg})$ and $4(5.0 \mathrm{mg})$, respectively. Fraction M18 was repurified by NP-HPLC, using a solvent mixture of DCM/acetone (15:1) to obtain 28 subfractions, M18-1-M18-28. Fraction M18-22 was separated by RP-HPLC, using a solvent mixture of $\mathrm{MeOH} / \mathrm{H}_{2} \mathrm{O}$ (1:1) to afford $5(1.0 \mathrm{mg})$. Fraction $\mathrm{Q}$ was separated on silica gel and eluted using n-hexane/EtOAc (stepwise, 4:1, pure EtOAc) to afford 25 subfractions, Q1-Q25. Fraction Q9 was further separated by reverse-phase $\mathrm{C} 18$ column, using a solvent mixture of $\mathrm{H}_{2} \mathrm{O} / \mathrm{MeOH}$ (stepwise, 80:20, pure $\mathrm{MeOH}$ ) to afford 18 subfractions, Q9A-Q9R. Fraction Q9G was separated on RP-HPLC and eluted with $\mathrm{MeOH} / \mathrm{H}_{2} \mathrm{O}(1: 1)$ as the mobile phase to afford 6 (2.0 $\left.\mathrm{mg}\right)$.

Briarenolide ZI (1): white powder; $\mathrm{mp} 292-293{ }^{\circ} \mathrm{C}$; $[\alpha]_{\mathrm{D}}^{25}-31$ (c 0.2, $\mathrm{CHCl}_{3}$ ); IR (neat) $v_{\max } 3382$, $1769,1715 \mathrm{~cm}^{-1} ;{ }^{1} \mathrm{H}\left(400 \mathrm{MHz}, \mathrm{CDCl}_{3}\right)$ and ${ }^{13} \mathrm{C}\left(100 \mathrm{MHz}, \mathrm{CDCl}_{3}\right) \mathrm{NMR}$ data (see Table 1); ESIMS: $m / z$ $555[\mathrm{M}+\mathrm{Na}]^{+}, 557[\mathrm{M}+2+\mathrm{Na}]^{+}$; HRESIMS: $m / z 555.16025$ (calcd. for $\mathrm{C}_{24} \mathrm{H}_{33} \mathrm{ClO}_{11}+\mathrm{Na}, 555.16036$ ).

Briarenolide ZII (2): white powder; $\mathrm{mp} 87-88^{\circ} \mathrm{C}$; $[\alpha]_{\mathrm{D}}^{25}-20\left(c 0.1, \mathrm{CHCl}_{3}\right)$; IR (neat) $v_{\max } 3481$, $1781,1733 \mathrm{~cm}^{-1} ;{ }^{1} \mathrm{H}\left(400 \mathrm{MHz}, \mathrm{CDCl}_{3}\right)$ and ${ }^{13} \mathrm{C}\left(100 \mathrm{MHz}, \mathrm{CDCl}_{3}\right)$ NMR data (see Table 2); ESIMS: $m / z 557[\mathrm{M}+\mathrm{Na}]^{+}$; HRESIMS: $m / z 557.23552$ (calcd. for $\mathrm{C}_{28} \mathrm{H}_{38} \mathrm{O}_{10}+\mathrm{Na}$, 557.23572).

Briarenolide ZIII (3): white powder; mp $173-174{ }^{\circ} \mathrm{C}$; $[\alpha]_{\mathrm{D}}^{25}+25\left(c 0.1, \mathrm{CHCl}_{3}\right)$; IR (neat) $v_{\max } 3444$, 1779, $1732 \mathrm{~cm}^{-1} ;{ }^{1} \mathrm{H}\left(400 \mathrm{MHz}, \mathrm{CDCl}_{3}\right)$ and ${ }^{13} \mathrm{C}\left(100 \mathrm{MHz}, \mathrm{CDCl}_{3}\right)$ NMR data (see Table 3); ESIMS: $m / z 503[\mathrm{M}+\mathrm{Na}]^{+}$; HRESIMS: $m / z 503.18858$ (calcd. for $\mathrm{C}_{24} \mathrm{H}_{32} \mathrm{O}_{10}+\mathrm{Na}$, 503.18877).

Briarenolide ZIV (4): white powder; mp $152-153{ }^{\circ} \mathrm{C}$; $[\alpha]_{\mathrm{D}}^{25}+64\left(c 0.3, \mathrm{CHCl}_{3}\right)$; IR (neat) $v_{\max } 3444$, $1778,1732 \mathrm{~cm}^{-1} ;{ }^{1} \mathrm{H}\left(400 \mathrm{MHz}, \mathrm{CDCl}_{3}\right)$ and ${ }^{13} \mathrm{C}\left(100 \mathrm{MHz}, \mathrm{CDCl}_{3}\right)$ NMR data (see Table 4); ESIMS: $m / z 575[\mathrm{M}+\mathrm{Na}]^{+}$; HRESIMS: $m / z 575.24645$ (calcd. for $\mathrm{C}_{28} \mathrm{H}_{40} \mathrm{O}_{11}+\mathrm{Na}$, 575.24628).

Briarenolide ZV (5): white powder; $\mathrm{mp} 192-193{ }^{\circ} \mathrm{C}$; $[\alpha]_{\mathrm{D}}^{25}+15\left(c 0.1, \mathrm{CHCl}_{3}\right)$; IR (neat) $v_{\max } 3445$, 1770, $1732 \mathrm{~cm}^{-1} ;{ }^{1} \mathrm{H}\left(400 \mathrm{MHz}, \mathrm{CDCl}_{3}\right)$ and ${ }^{13} \mathrm{C}\left(100 \mathrm{MHz}, \mathrm{CDCl}_{3}\right)$ NMR data (see Table 5); ESIMS: $m / z 505[\mathrm{M}+\mathrm{Na}]^{+}$; HRESIMS: $m / z 505.20460$ (calcd. for $\mathrm{C}_{24} \mathrm{H}_{34} \mathrm{O}_{10}+\mathrm{Na}$, 505.20442).

Briarenolide ZVI (6): white powder; mp $173-174{ }^{\circ} \mathrm{C}$; $[\alpha]_{\mathrm{D}}^{25}+70\left(c 0.3, \mathrm{CHCl}_{3}\right)$; IR (neat) $v_{\max } 3446$, $1772,1734 \mathrm{~cm}^{-1} ;{ }^{1} \mathrm{H}\left(400 \mathrm{MHz} \mathrm{CDCl}_{3}\right)$ and ${ }^{13} \mathrm{C}\left(100 \mathrm{MHz}, \mathrm{CDCl}_{3}\right)$ NMR data (see Table 6); ESIMS: $m / z 547[\mathrm{M}+\mathrm{Na}]^{+}$; HRESIMS: $m / z 547.21473$ (calcd. for $\mathrm{C}_{26} \mathrm{H}_{36} \mathrm{O}_{11}+\mathrm{Na}$, 547.21498).

\subsection{In Vitro Anti-Inflammatory Assay}

The murine macrophage (RAW264.7) cell line was purchased from American Type Culture Collection (ATCC) (Manassas, VA, USA). The in vitro anti-inflammatory activities of Compounds 1-6 were measured by examining the inhibition of LPS-induced upregulation of pro-inflammatory iNOS and COX-2 protein expressions in the macrophage cell line using Western blotting analysis [15-17]. Briefly, an inflammation response in macrophages was induced by incubating cells in medium containing only LPS (10 ng/mL) without compounds for $16 \mathrm{~h}$. For the anti-inflammatory activity assay, Compounds 1-6 and dexamethasone $(10 \mu \mathrm{M})$ were added to the cells $10 \mathrm{~min}$ before LPS treatment. After incubation, the cells were lysed for Western blot analysis. The immunoreactivity data were calculated with respect to the average optical density of the corresponding (LPS)-stimulated group. Moreover, the effects of Compounds $\mathbf{1 - 6}$ on the viability of RAW 264.7 cells were also evaluated by trypan blue staining [16,17]. For statistical analysis, the data were analyzed by one-way analysis of variance (ANOVA), followed by the Student-Newman-Keuls post hoc test for multiple comparisons. A significant difference was defined as a $p$-value of $<0.05$. 


\section{Conclusions}

Gorgonian corals belonging to the genus Briareum are proven to be rich sources of briarane-type compounds. Briarenolides ZII (2) and ZVI (6) are potentially anti-inflammatory compounds for future development $[18,19]$. This interesting species was transplanted to culture tanks located in the NMMBA, for extraction of natural material to establish a stable supply of bioactive substances.

Acknowledgments: This research was supported by grants from the Asia-Pacific Ocean Research Center, National Sun Yat-sen University; the National Museum of Marine Biology and Aquarium; the National Dong Hwa University; the Ministry of Science and Technology (Grant Nos. NSC 103-2911-I-002-303; MOST 104-2911-I-002-302, 103-2325-B-039-008, 103-2325-B-039-007-CC1, 103- 2325-B-291-001, 104-2325-B-291-001, 104-2320-B-291-001-MY3 and NSC 101-2320-B-291-001-MY3); the National Health Research Institutes (NHRI-EX103-10241BI); and in part by a grant from the Chinese Medicine Research Center, China Medical University (Ministry of Education, Aim for the Top University Plan), Taiwan, awarded to Yang-Chang Wu, Jyh-Horng Sheu and Ping-Jyun Sung.

Author Contributions: Yang-Chang Wu, Jyh-Horng Sheu and Ping-Jyun Sung designed the whole experiment and contributed to manuscript preparation; Yin-Di Su and Chun-Sung Sung researched the data; Zhi-Hong Wen, Yu-Hsin Chen, Yu-Chia Chang, Jih-Jung Chen and Lee-Shing Fang analyzed the data and performed data acquisition.

Conflicts of Interest: The authors declare no conflicts of interest.

\section{References}

1. Sheu, J.-H.; Sung, P.-J.; Huang, L.-H.; Lee, S.-F.; Wu, T.; Chang, B.-Y.; Duh, C.-Y.; Fang, L.-S.; Soong, K.; Lee, T.-J. New cytotoxic briaran diterpenes from the Formosan gorgonian Briareum sp. J. Nat. Prod. 1996, 59, 935-938. [CrossRef] [PubMed]

2. Sung, P.-J.; Sheu, J.-H.; Xu, J.P. Survey of briarane-type diterpenoids of marine origin. Heterocycles 2002, 57, 535-579. [CrossRef]

3. Sung, P.-J.; Chang, P.-C.; Fang, L.-S.; Sheu, J.-H.; Chen, W.-C.; Chen, Y.-P.; Lin, M.-R. Survey of briarane-related diterpenoids-Part II. Heterocycles 2005, 65, 195-204. [CrossRef]

4. Sung, P.-J.; Sheu, J.-H.; Wang, W.-H.; Fang, L.-S.; Chung, H.-M.; Pai, C.-H.; Su, Y.-D.; Tsai, W.-T.; Chen, B.-Y.; Lin, M.-R.; et al. Survey of briarane-type diterpenoids-Part III. Heterocycles 2008, 75, 2627-2648. [CrossRef]

5. Sung, P.-J.; Su, J.-H.; Wang, W.-H.; Sheu, J.-H.; Fang, L.-S.; Wu, Y.-C.; Chen, Y.-H.; Chung, H.-M.; Su, Y.-D.; Chang, Y.-C. Survey of briarane-type diterpenoids-Part IV. Heterocycles 2011, 83, 1241-1258. [CrossRef]

6. Sheu, J.-H.; Chen, Y.-H.; Chen, Y.-H.; Su, Y.-D.; Chang, Y.-C.; Su, J.-H.; Weng, C.-F.; Lee, C.-H.; Fang, L.-S.; Wang, W.-H.; et al. Briarane diterpenoids isolated from gorgonian corals between 2011 and 2013. Mar. Drugs 2014, 12, 2164-2181. [CrossRef] [PubMed]

7. Sung, P.J.; Su, J.H.; Wang, G.H.; Lin, S.F.; Duh, C.Y.; Sheu, J.H. Excavatolides F-M, new briarane diterpenes from the gorgonian Briareum excavatum. J. Nat. Prod. 1999, 62, 457-463. [CrossRef] [PubMed]

8. Sheu, J.-H.; Sung, P.-J.; Su, J.-H.; Wang, G.-H.; Duh, C.-Y.; Shen, Y.-C.; Chiang, M.Y.; Chen, I.-T. Excavatolides U-Z, new briarane diterpenes from the gorgonian Briareum excavatum. J. Nat. Prod. 1999, 62, 1415-1420. [CrossRef] [PubMed]

9. Sheu, J.-H.; Sung, P.-J.; Cheng, M.-C.; Liu, H.-Y.; Fang, L.-S.; Duh, C.-Y.; Chiang, M.Y. Novel cytotoxic diterpenes, excavatolides A-E, isolated from the Formosan gorgonian Briareum excavatum. J. Nat. Prod. 1998, 61, 602-608. [CrossRef] [PubMed]

10. Bayer, F.M. Key to the genera of Octocorallia exclusive of Pennatulacea (Coelenterata: Anthozoa), with diagnoses of new taxa. Proc. Biol. Soc. Wash. 1995, 94, 902-947.

11. Benayahu, Y. Soft corals (Octocorallia: Alcyonacea) of the southern Ryukyu Archipelago: The families Tubiporidae, Clavulariidae, Alcyoniidae and Briareidae. Galaxea 2002, 4, 11-32. [CrossRef]

12. Benayahu, Y.; Jeng, M.-S.; Perkol-Finkel, S.; Dai, C.-F. Soft corals (Octocorallia: Alcyonacea) from Southern Taiwan. II. Species diversity and distributional patterns. Zool. Stud. 2004, 43, 548-560.

13. Miyazaki, Y.; Reimer, J.D. Morphological and genetic diversity of Briareum (Anthozoa: Octocorallia) from the Ryukyu Archipelago, Japan. Zool. Sci. 2014, 31, 692-702. [CrossRef] [PubMed]

14. Fabricius, K.; Alderslade, P. Soft Corals and Sea Fans-A Comprehensive Guide to the Tropical Shallow-Water Genera of the Central-West Pacific, the Indian Ocean and the Red Sea, 1st ed.; Australian Institute of Marine Science: Queensland, Australia, 2001; Volume 55, pp. 154-157. 
15. Huang, S.-Y.; Chen, N.-F.; Chen, W.-F.; Hung, H.-C.; Lee, H.-P.; Lin, Y.-Y.; Wang, H.-M.; Sung, P.-J.; Sheu, J.-H.; Wen, Z.-H. Sinularin from indigenous soft coral attenuates nociceptive responses and spinal neuroinflammation in carrageenan-induced inflammatory rat model. Mar. Drugs 2012, 10, 1899-1919. [CrossRef] [PubMed]

16. Jean, Y.-H.; Chen, W.-F.; Sung, C.-S.; Duh, C.-Y.; Huang, S.-Y.; Lin, C.-S.; Tai, M.-H.; Tzeng, S.-F.; Wen, Z.-H. Capnellene, a natural marine compound derived from soft coral, attenuates chronic constriction injury-induced neuropathic pain in rats. Br. J. Pharmacol. 2009, 158, 713-725. [CrossRef] [PubMed]

17. Jean, Y.-H.; Chen, W.-F.; Duh, C.-Y.; Huang, S.-Y.; Hsu, C.-H.; Lin, C.-S.; Sung, C.-S.; Chen, I.-M.; Wen, Z.-H. Inducible nitric oxide synthase and cyclooxygenase-2 participate in anti-inflammatory and analgesic effects of the natural marine compound lemnalol from Formosan soft coral Lemnalia cervicorni. Eur. J. Pharmacol. 2008, 578, 323-331. [CrossRef] [PubMed]

18. Wei, W.-C.; Sung, P.-J.; Duh, C.-Y.; Chen, B.-W.; Sheu, J.-H.; Yang, N.-S. Anti-inflammatory activities of natural products isolated from soft corals of Taiwan between 2008 and 2012. Mar. Drugs 2013, 11, 4083-4126. [CrossRef] [PubMed]

19. Senthilkumar, K.; Kim, S.K. Marine invertebrate natural products for anti-inflammatory and chronic diseases. Evid. Based Complement. Altern. Med. 2013. [CrossRef] [PubMed]

(C) 2016 by the authors; licensee MDPI, Basel, Switzerland. This article is an open access article distributed under the terms and conditions of the Creative Commons by Attribution (CC-BY) license (http://creativecommons.org/licenses/by/4.0/). 